\title{
Didactic Nuances in Emeka Nwabueze's Presentation of Characters' Social Worldviews on Concealment/Deception in Spokesman for the Oracle and Rainstorm in the Desert
}

\author{
Emeka Aniago \\ Uche-Chinemere Nwaozuzu \\ Christian Maduka \\ Department of Theatre \& Film Studies, \\ University of Nigeria, Nsukka, Nigeria
}

DOI: https://doi.org/10.36941/ajis-2020-0o8o

\begin{abstract}
This study examines the application language and speech for the purpose of deception as a means of achieving concealment of information as portrayed in two plays of a Nigerian playwright Emeka Nwabueze. Thus, this study attempts to discuss some typologies of deception and concealment of information as a means of understanding better, the reasons and circumstances that inform the description of concealment of information as good, bad, devious, ugly, legal or illegal. This attempt will help us to interpret why and when concealment of information as well as deception are essential in achieving survival, progress, redress, defence, discovery, illumination, satisfaction or vendetta directly or indirectly. Though concealment of information can occur through inaction and nonverbal mediums, we are focusing on deception through language and speech, and how worldview aids in locale specific definition and perception of forms of deception and concealment of information. The discussion in this study revolves around interpretive analysis approaches as means of accessing applicability of some theories of concealment and deception in describing behaviours in these categories as universal common with shades of interpretive community perspectives. Lastly, the didactic relevance of Nwabueze's projection of presumed propelling forces and the consequences of concealment of information in the plays understudy, subsumes the understanding of deception as a universal common with trajectories of interpretive community suppositions.
\end{abstract}

Keywords: Concealment, deception, didactic, Emeka Nwabueze, worldview, ideology

\section{Introduction}

We shall start by saying that concealment of information and deception are natural phenomena to both humans and animals. Dependable contributions from major research efforts indicate that often times, survival, progress, redress, defence, discovery, illumination and satisfaction, directly or indirectly come thereof. Thus, because the practice of concealment of information remains a subsisting reality universally, scholars from diverse academic inclinations have continued to examine the circumstances that propel the application of concealment of information, how it is applied, the reason(s) why it may not be applied in some situations and circumstances, and the better appreciation of the possible consequence(s) resulting from different forms of application of 
concealment of information by people of different backgrounds, status, gender, age, and cultures. Hence, it is the realities of the illumination achieved in these scholarly interpretations that determine the categorization of concealment of information as bad, good, or ugly variously. Though concealment of information can occur through inaction and nonverbal mediums, we are focusing on deception through language and speech. Thus, we define concealment of information (in language and speech) as a voluntary and premeditated decision to disclose either nothing, insignificant, incomplete, or dishonest information, through deliberate misinformation, or withholding of information in a bid keep the needed facts hidden.

Language and speech are proven means of projecting characters' worldviews and visions on concealment of information in creative literature. Again it is clear that in scholarly analysis of language and speech as a means of advancing dependable attributions as regards to an individual's cognition, emotion, and inclinations, there are aspects that yield to application of theoretical frames that revolve around nuances of universal common. On the other hand, there are aspects of language and speech analysis that require the interpretation to be confined within the theoretical frames revolving around notions of interpretive community. These suppositions will be highlighted in the section of this introduction introducing relevant literature indicating the diversity of trajectories of studies looking at aspects of concealment of information. However, we want to point out that none of the studies in our review did focus on the didactic relevance of Emeka Nwabueze's ${ }^{1}$ authorial portrayal of concealment of information in Spokesman for the Oracle and Rainstorm in the Desert as a means of enhancing better understanding of the socio-cultural contexts of concealment of information. Furthermore, we will be applying concepts upholding concealment of information as a universal phenomenon and as a subsisting natural reality. Thus, this study adds to the existing body of knowledge on realities of concealment of information, particularly how Nwabueze as a playwright utilizes drama medium to project specific perspectives pertaining to didactic illumination of tragedy of devious concealment of information.

\section{Review of Literature}

The social contexts of concealment of information is a study area that can be examined from several perspectives such as 'morality of concealment of information' which is tackled within Religion, Philosophy, Sociology, and Psychology studies, as exemplified in the works of Fishbein et al (1979), Packer (1985), Molinsky et al (2005), and Shapira (2016); 'criminality of concealment of information' which majorly resonates in Psychology, Sociology, Law and Jurisprudence Studies and examples are the works of Hazelrigg (1969), Faulkner, et al (2003), Costas et al (2014), Gibson (2014), FATF Egmont Group (2018); 'socio-political problems and gains of concealment of information' which are mostly examined in Political Science, History, Military, Public Administration, and International Relations Studies as exemplified in the works of Betts (1982), Handel (1982), Kramer (1985), Cohen (2001), Ueda (2007), Harding (2009), Friedrichs (2010), and Schroeter (2013); 'impediments and gains of concealment of information' which are discussed within Business Administration, Education, Psychology, and Social Studies as portrayed in the works of Herek, et al (2002), and Livingston et al (2010), and 'concealment of information for confidentiality' which are variously assessed in Health, Legal, Clinical Practice, and Medical Studies as projected in the works of Beals, et al (2009), and Quinn (2017). More so, some multidisciplinary inclined studies attempt to differentiate between

\footnotetext{
${ }^{1}$ Emeka Nwabueze rose to Professor of Theatre \& Film Studies at the University of Nigeria, Nsukka where he bagged a BA in Theatre $\mathcal{E}$ Drama Studies before earning a PhD from USA. He has published ten plays: When the Arrow Rebounds which is an adaptation of Chinua Achebe's novel Arrow of God, The Dragon's Funeral, (a historical drama, which won the CVL prize for drama), A Dance of the Dead, (which was nominated for the Normal Prize), The Spokesman for the Oracle, (which has a filmic version), Echoes of Madness, A Parliament of Vultures, Guardian of the Cosmos, Heroes of Conscience, Fate of a Maiden and Lachrymose.
} 
outcomes caused by action vs. inaction as exemplified in Spranca et al (1991). In some cases and studies, the interpretation of inaction is mostly placed as voluntary decision to decline to disclose. Espousing on this supposition, Leslie K. John et al (2016) note that "declining a request to disclose often makes a worse impression even more than divulging unsavoury personal information" (p. 954). Furthering, they observe that there are "[...] those who withhold or fail to intuit this negative consequence" hence there are cases were "people withhold even when they would make a better impression by "coming clean”" (John et al, 2016, p. 954). In summation, they suggest that it is essential that "people should be aware not just of the risk of revealing, but the risk of hiding" (John et al, 2016, p. 954). Furthermore, John et al (2016), explain that "a similar dynamic is at play in the psychology of disclosure, where nondisclosure via commission (e.g., endorsing a 'choose not to answer' option) is likely judged more harshly than nondisclosure via omission (e.g., leaving a question blank), again due to greater perceived intentionality: unlike the volitional act of selecting 'choose not to answer,' someone could leave a question blank because he or she wants to withhold (i.e., intentional), or because he or she simply forgot (i.e., unintentional)" (p. 958). From the contribution of John et al, we learn that usually in some situations the choice to decline to offer response or information is taken as concealment of information and that in such situation, the individual in question is perceived as doing the wrong thing. Buttressing, John et al outline what they observe as the circumstances and variables that have the propensity to lead individuals to react in certain ways when they are faced with unambiguous option of full disclosure. These observations/suppositions are deductions emanating from seven experiments that explore people's decisions to share or withhold personal information, and the inclinations of observers to such decisions. Experiment ' 1 ' indicates that "when people choose not to reveal information - to be 'hiders' - they are judged negatively by others", whereas experiments ' $2 \mathrm{~A}$ ' and ' $2 \mathrm{~B}$ ' indicate that "these negative judgments emerge when hiding is volitional" and experiments ' $3 \mathrm{~A}$ ' and ' $3 \mathrm{~B}$ ', indicate that these tendencies "are driven by decreases in trustworthiness engendered by decisions to hide" (John et al, 2016, p. 954). Lastly, experiments ' $4 \mathrm{~A}$ ' and ' $4 \mathrm{~B}$ ' indicate that "hiders do not intuit these negative consequences: given the choice to withhold or reveal unsavoury information, people often choose to withhold, but observers rate those who reveal even questionable behaviour more positively" (John et al, 2016, p. 954). Furthermore, John et al (2016) leaning on their experiments' results indications are of the view that when people are "faced with decisions about disclosure, decision-makers should be aware not just of the risk of revealing, but of what hiding reveals" (p. 954). This contribution by John et al relate to the ideas of social construction of behaviour, which indicate that concealment can be looked at within locale specific worldviews and perspectives in pursuance of deep and dense interpretation of specific concealment patterns in relation to the influencing variables.

Also studies focusing on deception as tool for realizing concealment, attempt to distinguish between lies of omission which represents withholding the truth or instance of being economical with facts and lies of commission which represents stating things that are untrue or are deliberate premeditated misinformation to conceal known truth (Bok, 1978). The latter are perceived as more serious transgressions due in part to their greater perceived intentionality (Spranca et al, 1991). Though, some scholars believe that the cognition of deception is poorly understood (DePaulo et al, 2003), the act describable as deception is a premeditated process of leading another to believe something that the perpetrator clearly believes is untrue (Masip, et al 2004). These scholars also observe that deception comes in many forms, including falsification (lies), equivocation (evasion, ambiguity), exaggeration, understatement, and omission of vital/crucial information (Masip, et al 2004). The suppositions above, in many ways suggest that the ability and propensity to conceal information is not proportionally the same in every individual. This is because the influence of nature and nurture in determining cognitive evolution of individuals are not the same. Hence, it is plausible to debate that some individuals are better at concealing information than others. Thus, scientists studying lying have often postulated that it is more cognitively demanding than truth telling (e.g. Zuckerman, et al 1981; Sporer et al 2006; Vrij, et al 2008). More so, there are scholars, who acknowledge that lying as a means of concealment is phenomenally complex to grasp completely, 
thus it remains an intuitively appealing notion (DePaulo et al., 2003). According to Jeffry J. Walczyk et al (2014) serious deception, a term hereafter used interchangeably with high-stakes deception, can be defined "as an instance of deceit embedded in a social context in which sharing the truth might prove very costly to individuals" as it concerns meeting their goals and "for less serious deception, the potential cost of truth telling is small" (p. 22). Also some other scholars, attempt to present a clear understanding of classification of serious deceptions as those which are:

Fundamentally perceived as threats, transgressions and betrayals that result specifically in relationship problems, they endanger people's reputations and they are forbidden by organized religion and indictable by law. (DePaulo, et al 2004, 148)

Walczyk et al categorize and outline eight factors that act as motives of serious deception. Instrumental factor is when lie obtains rewards, power, social position, or other advantages, sometimes by exploiting others, whereby the perpetrator takes delight at a sense of control, excitement at prospect of reward, and greed (Walczyk et al, 2014, p. 26). Various interpretations of 'instrumental factor' are espoused in the works of Turner, et al (1975), Lindskold et al (1983), Camden, et al (1984), O'Hair et al (1994), and Depaulo et al (2004). Another factor is to avoid punishment whereby a lie prevents punishment or blame for liars of wrongdoing. In this case, lie is propelled by desire for a sense of relief and as a means of containing anxiety (Walczyk et al, 2014, p. 26). This factor is variously espoused in the works of Ekman (1989) and Depaulo et al (2004). The next factor is to protect self, hence individuals tell liar(s) to avoid confrontation or embarrassment and these are propelled by insecurity, and fear of embarrassment (Walczyk et al, 2014, p. 26). This factor is explained elaborately in the works of Turner, et al (1975), Seiter, et al (2002), and DePaulo et al (2004). Another factor is when the subject is propelled by the urge for self 'identity-relevance', 'selfpresentation', and 'face-saving' circumstances. In this case lies create false impressions about liars' identities or identity-relevant experiences (Walczyk et al, 2014, p. 26). Thus the desire for respect, sense of pride, and to reduce insecurity propel deception, and scholars such as Camden et al (1984), O'Hair et al (1994), McCornack (1997), and DePaulo et al (2004), in their works provided illuminating interpretations. The next factor is the desire to 'protect/help others'. This example represents an altruistic lie told to protect targets or others, propelled by compassion, empathy, and nurturance (Walczyk et al, 2014, p. 26). This factor is broadly discussed by Metts (1989), O'Hair et al (1994), Seiter et al (2002), and DePaulo et al (2004). Another factor is 'entitlement' whereby liars feel justified in hiding a truth they feel is unfairly disapproved or prohibited by people who are against the truth (Walczyk et al, 2014, p. 26). Hence this factor is instigated by sense of resentment or indignation (DePaulo et al, 2004). Another factor is the desire to 'hurt others', in which case a lie is shared in reprisal to hurt the target, hence anger and vengeance are the variables and they are espoused by O'Hair et al (1994), DePaulo et al (2004), and Walczyk et al (2014). Lastly the need to 'affect interpersonal relationships/affiliation' is another factor. In this case a lie is told to increase, decrease, maintain, or terminate interaction with another or control the intimacy as espoused by Turner et al (1975), Camden et al (1984), Lippard (1988), and Walczyk et al (2014).

\section{Synopsis of Rainstorm in the Desert}

The play's story begins with action at a police station. The central character Odogwu Nwogbo, a successful businessman, a postgraduate degree holder who is in his early forties is awaiting trial for alleged murder of his mother and wife. Odogwu returned to his village after spending a long time abroad in pursuit of wealth. He is determined to perform Abia dance, a highly revered mystical ritual dance, traditional to his community but his wife, mother and paternal uncle, (who incidentally is his biological father), are strongly against his decision. Thus his desire and his family members' opposition generate massive conflict which ends in tragedy. After his arrest and detention, Odogwu refuses to discuss the incidence leading to the demise of his mother (Ezinne) and wife (Ugoada). At 
some point, he speaks to a clinical psychologist Sister Rose. In their conversation, Odogwu narrates that he was propelled to ignore entreaties and disapprovals of family members because he felt that he satisfied all the strict compulsory stipulations of the ritual. The stipulations are that a person who intends to perform the ritual must be, a married man who is economically accomplished, a philanthropic free-born citizen of the village, must have a surviving biological male child, and his biological father must have died. However, as a result of concealment of information by Ezinne, Ugoada and Okosisi, ignorantly and stubbornly Odogwu performs the ritual which leads to tragic deaths. First Okosisi who is his biological father and legal father's younger brother mysteriously passed-on in his sleep the night after the dance. Thereafter, in his attempt to force out the truth from his wife and mother, inadvertently he kills both, one after the other.

\section{Synopsis of Spokesman for the Oracle}

Spokesman for the Oracle revolves around Ikem, a young medical student, his biological and legal father (Chidi) and his legal mother (Oyibo). The play's story relays how Ikem's father concealed that as a school principal, he had an affair with a student named Nneka and that he impregnated her. Eighteen years after Nneka wants Ikem back. Her attempt through deception leads to unravelling of deeply concealed information on all sides. It is this unravelling that leads to trajectories of agony, melancholy, disillusionment and tragedy. Eighteen years ago, Nneka was forced by circumstance to dispose her baby in the school's pit latrine. The cry of the baby alerted a student who promptly informed the principal (Mr. Chidi). Swiftly Mr. Chidi mobilized the school labourers and they successfully rescued the baby. Mr. Chidi took the baby to the social services, and requested that he be allowed to take and care for the baby, which was granted. Mr. Chidi's wife Oyibo who could not get pregnant lured Mr. Chidi to lie and tell the social services that the baby had died after being with them for a short while and Mr. Chidi acceded. On receiving the sad information, the social services thanked Mr. Chidi for his supposed effort in attempting to save and care for the baby.

This is how Ikem grew up to know them as his parents. However, the unravelling began when Ikem returned home to spend his vacation with his parents at the beginning of the semester break. He attended a pyjamas party organized by his friend Ofoma in celebration of his birthday reluctantly because he does not fancy night parties. This party happened to be Ikem's first ever 'alcohol only' party and he had never consumed alcoholic beverage before. It is because Ikem still struggled with shyness that the sustained lure by his friend Ofoma made him to succumb. Meekly he accepted to drink some beer.

As he sips it gradually to generate sufficient sense of belonging, he did not know when his drink was laced with either whisky or rum by a dashing young lady Nneka (about thirty-five years old). As Ikem gets overwhelmed by alcohol, Nneka who is on the instance of Ofoma to tease Ikem for a one night romantic fling takes Ikem into a room where they had sex through the night. In the morning Nneka who did not know that Ikem is her biological son whom she disposed in the school latrine eighteen years ago, whom she returned from Lagos to seek, leaves without any display of emotion towards the naive boy still in bed under massive hangover. Later Ikem went home with the help of his friends Ossy and Ofoma. On sighting Ikem in a dishevelled and drunk state, Oyibo becomes sad. As Ikem is still drowsy, he is helped to his bedroom. Later in the day, Ikem gets out of bed, walks up to Oyibo and tenders fervent apology with apparent remorse for his supposed bad behaviour. Oyibo accepts his apology and Ikem goes to the library to collect a book he ordered. Thereafter, Nneka's father Amadi, who is Ikem's biological maternal grandfather arrives to request for Ikem. Amadi wants Ikem back temporary, so that he can be part of a purported ritual of atonement prescribed by a mystic for the purpose of lifting a mysterious affliction troubling Nneka. Nneka told her father that she returned home from Lagos because of the ritual of atonement. This request did not go down well with Mr. Chidi, who roundly refuses, but requests for Nneka to visit him for an amicable discussion. 


\section{Comparing the Plays' Nuances of Concealment of Information and Tragic Outcomes}

In the two plays there are instances of concealment of information that emanates from the perpetrators decision to protect self from consequences of action such as embarrassment, punishment, and condemnation; to protect an individual they love from serious psychological distress, and probably to hurt someone for a reason or another. Looking at the case of attempting to avoid embarrassment and to save self or someone from emotional trauma through concealment of information, in Spokesman for the Oracle the apology tendered by Ikem to Oyibo for his sleeping out and coming home drunk subsumes these factors.

Ikem: Mum, I never planned to sleep outside. I just wanted to keep the company of my friends for a while. It was my first time of attending such a party. I was sitting down there watching them when I was told that it looked odd for me to sit there and watch them drink, especially as they were all in a state of euphoria. There were no soft drinks there, not even wine, only beer, rum and whisky. So I picked up a can of beer and decided to keep sipping it till I was ready to come back home. Then someone put some rum or whisky into it. A lot happened there mum, but I promise not to be so stupid again. If you can only pardon me and let's forget it ever happened. (Nwabueze 2011, p. 21)

Hearing Ikem's fervent and apparent sincere apology, Oyibo promptly accepts. However, Ikem cleverly conceals having had sex with a total stranger (Nneka) the night before. Thus, one wonders whether his choice to conceal this information is because he feels exceedingly ashamed or he is terrified to disclose it because of the probable backlash. May be he does not want to hurt Oyibo with such 'dark' information. Also, it is clear that Ikem's unsavoury experience at the party sets in motion other actions and revelations that lay bare years of 'dark concealments' by Ikem's legal and biological father Mr. Chidi about Ikem's paternity, the story about his disposal by his biological mother Nneka, and Mr. Chidi's concealment of the information from Oyibo that he impregnated Nneka. Clearly, Ikem's decision to conceal having had sex with a stranger while he narrates his apology to Oyibo is to protect self from embarrassment which is in line with the views espoused by Turner, et al (1975), Seiter, et al (2002), DePaulo et al (2004), and Walczyk et al (2014) in their contributions. Also the playwright's projection of Ikem as good boy who cares very much for Oyibo and Mr. Chidi may be part of the reason propelling his decision to conceal that bit of information because he intends to protect them. This is a factor described variously as altruistic behaviour driven by compassion and empathy as interpreted in the works of Metts (1989), O'Hair \& Cody (1994), Seiter et al (2002), and DePaulo et al (2004). Similarly, in Rainstorm in the Desert Okosisi's opposition to Odogwu's participation in the Abia dance captured in the dialogue below is an example of deception aimed at concealment of information just as Ikem in his apology to Oyibo.

Odogwu: Uncle, with due respect, I would like you to tell me why you do not want me to be the Abia laureate?

Okosisi: The consequences are enormous. It is an activity that involves the living, the dead and the unborn. There are many restrictions, hidden and transparent involved in that traditional activity and it is better for a wise man to avoid getting involved because of hidden consequences. (Nwabueze 2019, $p$. 34)

Just as Ikem in Spokesman for the Oracle, Okosisi's deception and concealment of information is most likely propelled by the desire to protect Odogwu from public embarrassment. This is because Odogwu is his biological son and the playwright suggests that Okosisi shows clear fatherly support and care towards Odogwu. Also Okosisi's concealment of information through deception is also possibly done to protect self from embarrassment and punishment. However, while Ikem may not necessarily have applied deception in the apology he tendered to Oyibo to avoid punishment, it is plausible to say that Okosisi's continued concealment of information even in the face of the ultimate risk of death if Odogwu goes ahead to perform the Abia dance is beyond avoidance of embarrassment 
but avoidance of strict punishment, which is in line with the positions of Ekman (1989), Depaulo et al (2004), and Walczyk et al (2014).

Furthermore, just as Okosisi strives to dissuade Odogwu from performing the Abia dance to avoid unravelling his concealment, Odogwu's wife also attempts assiduously to dissuade Odogwu from performing the dance because her own concealment is threatened too. The following conversation indicates this attempt by Ugoada, Odogwu's wife.

Odogwu: But sweet, you have always complained that I don't participate in the traditional affairs of the community, that I am almost standoffish. Now that I have given a nod to your ideas, you turn to the opposite direction.

Ugoada: I didn't mean you should participate in traditional activities to the level of absurdity. There are traditional dances, masquerade performances, and other aspects of traditional culture. They are the ones I was referring to not this one. (Nwabueze 2019, p. 27)

We can deduce from the conversation that Ugoada's motivating factors to continue her concealment of information is very similar to that of Okosisi. However, Odogwu's assessment of his wife's logic did not convince him to drop his intent to perform the dance. On her part, Ugoada did not relent; hence she reshuffles her approach and continues her attempt to dissuade Odogwu as exemplified in the following dialogue.

Ugoada: I am really afraid of the outcome of that dance. I'm not comfortable with the stipulations of the requirements.

Odogwu: Are you afraid I will not live up to expectation? You should trust your husband's resourcefulness as well as his ability to evaluate every situation very carefully before embarking on it.

Ugoada: My spirit is reluctant to accommodate the activity. I have the feeling that this is a time of catastrophe and disaster. One has to be careful with everything he embarks upon especially in the traditional society. (Nwabueze 2019, p. 28)

Although through dense allusion, Ugoada's expression appear to suggest her knowledge of what will happen if Odogwu goes ahead to perform the Abia dance, yet Odogwu remains oblivious. The choice of approach to protect herself from possible disaster propels her to intensify her attempt to dissuade her husband because the impending result of the concealment of information by her will instigate monumental tragedy.

While in Spokesman for the Oracle Chidi is not dissuading anybody from engaging in an activity that will spell doom just an Okosisi and Ugoada are doing because he is not seeing imminent monumental tragedy. Ugoada is seriously worried because Odogwu did not know that he does not have a biological son as stipulated by tradition for qualification to perform the Abia dance. It is apparent in the dialogue between Odogwu and Ugoada that Odogwu's comment indicates that he is at pains with the incongruity and inconsistency of his wife's position. The didactic nuance here is that such clear change of stance by his wife could have been a good signal that would have set off the mental alarm that would suggest to him that something is amiss.

Another dimension that requires closer attention is the behaviour of Odogwu's friend Obi. Whereas everyone who has something to hide is striving to dissuade Odogwu from performing the dance, Obi relentlessly encourages him. So what is his motivating reason to encourage his friend to plunge into a massive disaster? In line with the views of O'Hair et al (1994), DePaulo et al (2004), and Walczyk et al (2014), Obi apparently aims to hurt others because of anger or vengeance. Also unlike the others such as Okosisi and Ugoada who will pay a direct serious price if Odogwu goes ahead to perform the dance, he has no such monumental price to pay except condemnation by people. So the supposition here is that some people are willing to face damaging consequence so long as they inflict more damaging consequence on others, particularly those they singled out to hurt. In Rainstorm in the Desert Nwabueze's portrayal of Obi's behaviour makes him a despicable person based on the nature and circumstance of his concealment of information, whereas in Spokesman for the Oracle the 
friends of Ikem are portrayed differently. Ikem's friends concealed information from Ikem which indirectly leads to his travail but they are not viewed as devious as Obi in Rainstorm in the Desert. Ikem's friends where playing 'adolescent pranks' which the society does not view as utterly condemnable and devious as compared to Obi's conduct.

The following conversation clearly indicates that Obi and Okosisi are at cross purposes. The playwright projects Obi as the most devious character because he behaves as if he earnestly has Odogwu's interest and support at heart by sanctimoniously aligning himself with him whereas he deceitfully conceals information which may contribute to Odogwu's calamity.

Obi: Sir, I do not think there are hidden consequences.

Okosisi: A wise man does not beat the war drum if he is not ready for war.

Odogwu: Uncle, there's no need of talking about war in this situation. I'm wise enough to know how to avoid anything that portends war.

Okosisi: Wisdom is like a vast desert and cannot be covered in simplicity. I hear you talk about integrity. You already have enormous integrity, and you have the respect of all members of the community. You do not need the Abia dance for additional integrity. One does not need to climb the palm tree in order to drink palm wine. (Nwabueze 2019, p. 34)

As Odogwu remains adamant and unconvinced because Okosisi is speaking in riddles and metaphor, Okosisi gets increasingly disheartened, however he goes ahead to attempt to dissuade Odogwu as exhibited in the following conversation.

Okosisi: You're only chewing the chord of foolishness. Abia dance is so intricate that you think you know but you do not know the meaning of what you think you know.

Odogwu: Uncle, I can assure you that before taking this decision, I carried out extensive research on that and other traditional activities involved in it. I'm couched that I am in a perfect position to be the Abia dancer.

Obi: What is there to be afraid of? The main stipulations are that the person's father must have joined the ancestors, else he will be compelled to join them soon after; that the person should be a married man, have a son, and must never have been involved in forced sex or violation of another's spouse. (Nwabueze 2019, pp. 35-36)

Clearly through Okosisi's devious concealment and Odogwu's presumption of sufficient wisdom, Nwabueze intricately projects an intense conflict between disenchantment on the part of Okosisi and disillusionment on the part of Odogwu. Okosisi's choice of deep and dense ambiguity in his expression of intent to Odogwu is not helping Odogwu to clearly appreciate what he is alluding to. This indicates that metaphor and riddles can be tools of concealment of information in some circumstances. Thus, we deduce that Okosisi is at pains on how to dissuade Odogwu from going on with his proposition; hence we can analyze his propelling factors as avoidance of punishment and shame. It is understandable that Okosisi prefers persuasive words to a full disclosure of his devious concealment because he considers the enormity of shame that will come his way if he embraces full disclosure. Hence, Okosisi choice of concealment and projection of his views through veiled responses and comments cannot be said to be very shrewd since the likely aftermath will be tragic.

On the other hand, Odogwu's adamant disposition places him as one who despite his academic and business successes lacks meticulous awareness about human capacity and penchant to misinform and deceive even when they are close and family. This is because he blindly relied on his personally assumed facts as his basis for making a supposed rational choice that resulted in tragedy. He failed to read meaning(s) embedded in the sudden volte face of his wife and the total alignment of all his immediate adult family members against his decision as an ominous sign. The bone of contention between Okosisi and Odogwu is that while Odogwu feels that he is eminently qualified and mentally ready for the ritual because he is convinced that he satisfies all the stipulations as he boldly states: "My dear father died a long time ago, I'm married and I have a son, I have never polluted myself through involvement in the vices enumerated" and "I know myself more than you do" (Nwabueze 
2019, p. 36).

In Rainstorm in the Desert, the playwright portrays Okosisi as an example of such individuals who will choose to remain adamant, continue with concealment even when it is unambiguously evident that he will pay a heavy or ultimate price. Thus Okosisi had the option of embracing full disclosure and its consequence which will spare his life, rather he chooses the option of remaining adamant which led to his death. However, in Spokesman for the Oracle, the playwright presents Chidi differently. Although in the following conversation Chidi feebly remained in the path of deception, eventually he caved in and requests for a discussion with Nneka to find possible way(s) of resolving the conflict.

Amadi: Gently. A certain baby was dug up from the school latrine. He was thrown in there by someone, by one of your students...

Chidi: I don't know what you're talking about.

Amadi: You'll remember when I finish. (Sips his beer) Mr. Okafor, one of your students heard a baby's cry in the latrine and called your attention. You acted fast. You mobilized the school labourers and the baby was rescued. It was a male. Please, allow me to finish. You invited the social welfare to take custody of the baby while you struggled to discover the student who had the baby. After nearly a month of fruitless effort, you abandoned the search.

Chidi: You...

Amadi: Wait. Let me finish. You later requested the social welfare to allow you collect the baby and they did. You then collected the baby. Shortly after that, you left the east ... (Nwabueze 2011, pp. 30 - 31)

The above discussion reveals the beginning of unravelling of the 'dark' concealment of information by Mr. Chidi. It also flips open the premeditated intent that led to concealment of information on circumstances surrounding Ikem's birth and the truth about his biological parentage. Furthermore, this conversation presents shades of attempt by Mr. Chidi to continue with concealment of information, however the didactic tangent is that concealed information may not be so forever and that the revelation which occurs does have impact on the aftermath of a full disclosure. Another layer of concealment of information surrounding Ikem began after few weeks $\mathrm{Mr}$. Chidi reported to the social welfare that baby Ikem is dead. Mr. Chidi's concealment at this point towards the social welfare made it possible for him and his wife Oyibo to keep the baby as their biological child. Hence the question the playwright puts forward metaphorically is; can there be true love existing between individuals who have dark concealments such as that which Mr. Chidi and Oyibo created, nourished and protected with deceit, lies and charade? Their concealment of information is a deception on the entire society because they concealed the true identity of Ikem for personal gains and interest. This simply goes to suggest that they have to falsify documents through deliberate deception to obtain necessary papers for Ikem.

Thus as part of the first tragic aftermath of the concealment by Mr. Chidi, which keeps Ikem from knowing his biological mother, is his having sexual intercourse with her at the pyjamas party. In deep melancholic sadness Ikem wonders:

She couldn't have come to look for my mum. She's very selective and would have nothing to do with a person of that calibre. Yes. My mum had a worried look when she came out. She told me she wasn't worrying about what happened in the morning. And she never tells me a lie. Oh God! I've already suffered much between yesterday and today. This girl should not come here to add more darkness to my darkness. Ofo, you're the cause of this. You brought me into that hopeless party. You asked her to come to me and [...]. (Nwabueze 2011, p. 57)

In both Rainstorm in the Desert and Spokesman for the Oracle Nwabueze indicates that the aftermath of devious concealment may result in serious tragedy and the revelation of the concealed information pushed both Ikem and Odogwu to the brink. Both Ikem and Odogwu similarly, reeling in shock and surprise that they have been with people who on the surface appear kind, loving, caring, and trustworthy have been deceiving them for years. On his part, Odogwu who could not believe the 
revelation initially, thus he seeks clarification from the village seer who affirms the elders' position that Okosisi is his biological father. As his consultation with the village seer validates this disturbing information, Odogwu confronts his mother demanding for her candid response. At this point, Nwabueze portrays how revelation of devious concealment of information can rapidly make one who loves and cares for someone could become dangerously furious, disenchanted, demented or psychotic. Furthermore, Nwabueze indicates that initial concealment of information usually leads to further attempts to conceal, hence after initial attempt at denial, Ezinne affirms the revelation. She blames Okosisi, suggesting that he lured her at a most vulnerable period. Thus Odogwu learns from Ezinne that his legal father left her in the village with her two daughters under the care of Okosisi. This is because he travelled to Kano to make arrangement for their relocation after his transfer from Markudi as a postman. However, Odogwu learning of this age long deception gets very furious at Ezinne as she tactically blames loneliness for her inability to resist Okosisi. In his rage, he grabs her arm tightly and she protests. Propelled by reflex, Odogwu releases his grip and Ezinne takes the opportunity to escape further manhandling. Accidently she trips, smashes her head on the wall, collapses awkwardly and dies. In response, Odogwu rushes to her and tries to revive her without success. After awhile, Ugoada walks in, and beholds Ezinne's lifeless body. Impetuously she rants at Odogwu who responds by grabbing her neck, and demands furiously for validation of their son's paternity. Just like Ezinne, after initial feeble attempts at evasion, she insinuates that Obi is their son's biological father. Through this scenario, Nwabueze indicates that those who parade sanctimoniously as friend could be more devious and deadly.

\section{Conclusion}

This paper looks at the variables and nuances of concealment of information in these two plays as means of deepening our appreciation of the didactic shades and meta-philosophical metaphors of deception realities and consequences. Our view is that the act of concealment is that which is influenced by an individual's nature and nurture, so individuals get better at concealing information as they horn their skill in this direction. Therefore, concealment of information is a human reality that plays out in everyday of an individual's life, and in some cases it can be applied to make huge progress, save life and change circumstances for good. Thus, Nwabueze in the plays Spokesman for the Oracle and Rainstorm in the Desert through creative application of language/speech suggests some of the circumstances that propel individuals to choose concealment of information when there is the option of full disclosure. We also learn that human behaviour as regards to concealment of information is a multi-faceted, complex and dynamic field of study, which allows different shades of interrogation to establish plausible insights. Therefore a study of this kind helps in laying the foundation for determination of many aspects of human deception tendencies. Thus, deep understanding of human propensity towards deception is a tricky task bearing in mind that humans are constantly adapting and changing to fit into their re-aggregating environment. We also acknowledged in this study that everyone is in one way or another a victim and that practically everyone directly or indirectly is a perpetrator. We also recognized that pain of concealment of information emanates from forces that propel full disclosure and consequences are usually damaging. We also acknowledged that concealment can be viewed differently based on the viewer's worldview, perspectives and inclinations. Thus concealment of information is in some circumstances and jurisdictions viewed differently or similarly as illegal, legal, tenable, vicious, good, bad or ugly and that the quality of concealment is in many ways propelled by 'natural talent', 'training', 'experience', and 'effort'. In the end, this paper relates that Nwabueze's attempt in Spokesman for the Oracle and Rainstorm in the Desert reassesses some concealment of information instigating factors, the place of cognition and reflex as a perpetrator or a victim and the interpretive community dimensions and universal common polemics. 


\section{References}

Beals, K. P., Peplau, L. A., \& Gable, S. L. (2009). 'Stigma management and well-being: The role of perceived social support, emotional processing, and suppression' Personality E Social Psychology Bulletin, 35 (7), 867 - 879.

Bell, E. (2009). 'Concealing and disguising criminal property' Journal of Money Laundering Control, $12(3), 268$ 284.

Betts, R. K. (1982). Surprise attack: lessons for defense planning. Washington, D.C.: Brookings Institution.

Bok, S. (1978). Lying: moral choices in public and private life. New York: Pantheon.

Camden, C., Motley, M., \& Wilson, A. (1984). 'White lies in interpersonal communication: a taxonomy and preliminary investigation of social motivations' Western Journal of Speech Communication, 48, 309 - 325.

Cohen, S. (2001). States of denial: Knowing about atrocities and suffering. Malden: Blackwell Publishers.

Costas, J., \& Grey, C. (2014). 'Bringing secrecy into the open: Towards a theorization of the social processes of organizational secrecy' Organization Studies, 35(10), 1423 - 1447.

DePaulo, B. M., Ansfield, M. E., Kirkendol, S. E., \& Boden, J. M. (2004). 'Serious lies' Basic and Applied Social Psychology, 26, $147-167$.

DePaulo, B. M., Lindsay, J. J., Malone, B. E., Muhlenbruck, L., Charlton, K., \& Harris, C. (20oz). 'Cues to deception’ Psychological Bulletin, 129, 74 - 112.

Ekman, P. (1989). Why kids lie: How parents can encourage truthfulness. New York: Penguin.

FATF - Egmont Group. (2018). Concealment of beneficial ownership, FATF, Paris, France, www.fatfgafi.org/publications/methodandtrends/documents/concealment-beneficial-ownership.html

Faulkner, R. R., Cheney, E. R., Fisher, G. A., \& Baker, W. E. (2003). 'Crime by committee: conspirators and company men in the illegal electrical industry cartel, 1954 - 1959' Criminology, 41(2), 511 - 554.

Fishbein, M. J. \& Laird, J. D. (1979). 'Concealment and disclosure: Some effects of information control on the person who controls' Journal of Experimental Social Psychology, 15(2), 114 - 121.

Friedrichs, D. O. (2010). Trusted criminals, white collar crime in contemporary society. Belmont: Wadsworth.

Gibson, D. R. (2014). 'Enduring illusions the social organization of secrecy and deception' Sociological Theory, $32(4), 283-306$.

Handel, M. I. (1982). 'Intelligence and deception' Military Deception and Strategic Surprise. Gooch, J. \& Perlmutter, A. (Editors). N.J.: Frank Cass \& Co., $122-154$.

Harding, C. (2009). 'Capturing the cartel's friends: Cartel facilitation and the idea of joint criminal enterprise' European Law Review, 34(2), 298 - 309.

Hazelrigg, L. E. (1969). 'A re-examination of Simmel's the secret and the secret society: Nine propositions' Social Forces, 47(3), 323-330.

Herek, G. M., Cogan, J. C., \& Gillis, J. R. (2002). 'Victim experiences in hate crimes based on sexual orientation' Journal of Social Issues, 58(2), 319 - 339.

John, L. K., Barasz, K., \& Norton, M. I. (2016). 'Hiding personal information reveals the worst' PNAS, 113(4), 954 959.

Kramer, R. C. (1985). 'Defining the concept of crime: A humanistic perspective' The Journal of Sociology E Social Welfare, 12(3), Article 4, $469-487$.

Lindskold, S., \& Walters, P. S. (1983). 'Categories for acceptability of lies' Journal of Social Psychology, 120,129 136.

Lippard, P. V. (1988). 'Ask me no questions, I'll tell you no lies: Situational exigencies for interpersonal deception' Western Journal of Speech Communication, 52, 91-103.

Livingston, J. D., \& Boyd, J. E. (2010). 'Correlates and consequences of internalized stigma for people living with mental illness: A systematic review and meta-analysis' Social Science E Medicine, 71(12), 2150 - 2161.

Masip, J., Garrido, E., \& Herrero, C. (2004). 'Defining deception' Anales de Psicología, 20, 147-171.

Molinsky, A., \& Margolis, J. (2005). 'Necessary evils and interpersonal sensitivity in organizations' Academy of Management Review, 3o(2), 245 - 268.

Nwabueze, E. (2019). Rainstorm in the Desert. Enugu: CNC Publications.

Nwabueze, E. (2005). The Dragon's Funeral. Enugu: ABIC Publishers.

Nwabueze, E. (2011). Spokesman for the Oracle. Enugu: ABIC Books \& Equip. Ltd.

O’Hair, H. D., \& Cody, M. J. (1994). 'Deception' The Dark Side of Interpersonal Communication, Cupach, W. R. \& Spitzberg, B. H. (Eds.), Hillsdale, NJ: Erlbaum, 181-213.

Packer M. J. (1985). 'Concealment and uncovering in moral philosophy and moral practice' Human Development, $28,108-112$.

Quinn, D. M. (2017). 'Issue introduction: Identity concealment, multilevel predictors, moderators, and consequences' Journal of Social Issues, 73(2), 230 - 239. 
Schroeter, M. (2013). Silence and concealment in political discourse. Philadelphia: John Benjamins.

Seiter, J. S., Bruschke, J., \& Bai, C. (2002). 'The acceptability of deception as a function of perceivers' culture, deceiver's intention, and deceiver deceived relationship' Western Journal of Communication, 66(2), 158 180.

Shapira, R. (2016). Ignorance-concealing use of immoral means by 'jumpers', a covert corrupting practice that nurtures amoral executives https://ssrn.com/abstract=2907562 or http://dx.doi.org/10.2139/ssrn.2907562

Sporer, S. L., \& Schwandt, B. (2006). 'Para-verbal indicators of deception: A meta-analytic synthesis' Applied Cognitive Psychology, 20, $421-446$.

Spranca, M., Minsk, E., \& Baron, J. (1991). 'Omission and commission in judgment and choice' Journal of Experimental Social Psychology, 27, 76 - 106.

Turner, R. E., Edgley, C., \& Olmstead, G. (1975). 'Information control in conversations: Honesty is not always the best policy' Kansas Journal of Sociology, 11, $69-89$.

Ueda, A. (2007). Concealment of politics, politics of concealment: The production of 'literature' in Meiji Japan. Stanford: Stanford University Press.

Vrij, A., Fisher, R., Mann, S., \& Leal, S. (2008). 'A cognitive load approach to lie detection' Journal of Investigative Psychology and Offender Profiling, 5, $39-43$.

Walczyk, J. J., Harris, L. L., Duck, T. K. \& Mulay, D. (2014). 'A social-cognitive framework for understanding serious lies: Activation-decision-construction-action theory' New Ideas in Psychology, 34, 22 - 36.

Zuckerman, M., DePaulo, B. M., \& Rosenthal, R. (1981). 'Verbal and nonverbal communication of deception' Advances in Experimental Social Psychology, 14, 1 - 59. 